\title{
IMPLEMENTATION OF FOOD SAFETY ACTIVITIES: THE CASE STUDY IN MANDARIN ORANGE FARMERS BY AGRICULTURE COOPERATIVE IN JAPAN
}

\author{
Okta Pringga Pakpahan ${ }^{1 *}$, Kenji Hosono ${ }^{1}$, Masahiro Yamao ${ }^{1}$ and Yoshiharu Shiratake ${ }^{2}$ \\ ${ }^{1}$ Hiroshima University, Japan \\ ${ }^{2}$ Department of Agricultural Economics, Saga University, Japan \\ Email:*al_ghifari3@ymail.com
}

\begin{abstract}
A number of high outbreaks have raised questions regarding food quality and safety assurance. Agriculture cooperatives as food business operators have a central role, challenged to maintain standard demanded by customers, government, and international code which are incorporated into their operations activity. The objective of this study was to investigate the role of cooperatives in implementing food safety management at production (farmers) and consumer (exporters, retailers or wholesale) levels. The research employed case studies in prefecture-level cooperatives in Japan. Data were collected with a diagnostic tool for evaluation of food safety activities on farms and traders and semi-structured interviews with safety assurance managers of the cooperatives. Thirty mandarin orange farms, two traders, three cooperative staff, one processing company and one exporter association, were evaluated. The findings indicate that cooperatives have the double responsibility of managing quality and safety in the food chain. They are responsible for operational decisions taken by farmers during cultivation period. At the same time, they make the tactical decision concerning of quality and safety requirements between customers, and farmers, including selling the products. Hierarchical relationships farmers with cooperatives and customers with cooperatives show the good level in food safety activities (score 2). Therefore, this study useful for assist quality assurance system into the food industry and agriculture sector in Japan.
\end{abstract}

Keywords: agricultural, cooperatives, food safety

\section{Introduction}

The risk of contamination is inherited since the output of one chain actor is the input for the next. Addition, the performance of implemented food safety activities in food chain determine how satisfactory or unsatisfactory the output. In line with theses idea, Verbekeet et al., (2006) define food has three credence attributes specifically classified cannot verify consumers themselves. Firstly, credence production has concern the origin of the product (e.g., GMO, organic). Secondly, credence processing has concentration the way food processing from raw material (e.g., free of additives, GM ingredients). Thirdly, credence product contents had relating nutrient and contamination of food (e.g., gluten, dioxin contamination).

In Japan, Agriculture cooperative had established nationwide by Japan government in 1947, in collaboration with Ministry of Agriculture, Forestry, and Fisheries (MAFF) (Godo, 2014). The principal activities provide essential information, comprehensive service (i.e., procurement of input and marketing of produce), transferred knowledge and guided the farmers on farming activity to produce agricultural commodities (Imran et al., 2014). In additionally, cooperative also have responsibilities quality control of the product which selling under a cooperative brand. Therefore, during cultivation period cooperatives provide several activities to ensure the safety and quality product their members are meet with consumers requirements. 
In order to consumer protection, food safety activities held by agriculture cooperative has arisen a question relating to Quality Assurance (QA), control and monitoring systems are implemented in farms members. Since, the study in Thailand (Pongvinyoo, 2015) and Myanmar (Waiyeelin, 2016) showed the QA at farm level (cultivation process and product standards) is the critical point in the safety food chain. Moreover, food safety hazards are related consumption of fresh produce such as Salmonella spp. (e.g., tomato, cilantro, peppers), Escherichia coli 0157:H7 (e.g., spinach), Listeria monocytogenes (e.g., cantaloupe outbreak) (Altmann et al., 2011; Barton Behraveshet et al., 2011; Laksanalamai et al. 2012) appears due to the absence of an adequate treatment before consumption.

The primary objective of this paper was to evaluate food safety activities in mandarin orange at Saga prefecture, Japan. Specifically, this paper explores food safety activities during cultivation period, then assessing the current status of food safety activities.

\section{Quality assurance concepts}

Quality assurance (QA) defined by Cruz et al. (2006) as the procedural and operational framework used by an organization managing activity dealing with control of quality in each step of the process to prevent all hazards involved in the food processing steps. Luningand Marcelis(2006) define QA systems onto assurance of food safety depend on technological and managerial aspects. It implies that the safety of the final product is a result of product characteristics and process conditions (technological), and human behavior and working conditions (managerial) on the other hand.

The application of QA systems helps in identifying and managing the quality hazards and risks occurring in the production process, and in providing the consumer with more certainty about the quality of products of origin (Noordhuizen and Metz, 2005). However, the way in implementing systems and contexts QA which food industry decides to take it depends on necessary consumers and production chain (Kupper and Batt, 2009).

Several of food safety hazards are related to the consumption of fresh produce due to natural contaminants are arises from many sources (production activity, postharvest handling, and processing) (Beuchat, 1996).Such as Salmonella spp (e.g., a tomato-cilantro-peppers outbreak in the USA in 2008), toxigenic molds produce mycotoxins which are a group of chemical substances commonly grow on fruits (Van de Perre et al., 2013) and pesticide residues (Van Boxstael et al., 2013). All these groups of hazards were taken into account in the analysis of food safety activities in farms.

\section{Materials and Methods}

This paper uses data from mandarin orange farms in Saga Prefecture, Japan. Midori area was selected purposively due to the central suppliers export of mandarin orange in Saga Prefecture.. The sample included thirty mandarin orange farms, two traders, three cooperative staff, one processing company and one representative exporter association. This study was employed Techno-Managerial approach. It allows studying the dependence of food safety on the dynamics of the food system. It implies that the final product is a result of reflected the technological applied during the process and managerial capability with respect to assurance of food safety and environmental conditions. In the total, 22 indicators of activities were presented to the respondents. Then, all indicators were ranked by their means and evidence to evaluate the level of food safety status. The descriptive analysis was used to interpret the results analysis. 


\section{Results}

\section{Status of food safety activity applied}

Control activities

Table 1 shows the results for the indicators of the actual operation of control activities. The situation of cooperative scored 3 (advanced level), corresponding to easily available and understandable procedures that were regularly updated. Staff in cooperative were aware of the content of procedures and were strictly following them. Even though farmers were mostly working according to habits, the staff of cooperatives gives a lot of support to make sure the producers comply with their standards. All analyses related to pest, waste and chemical compounds were done by external accredited labs (score 3, advanced level). Lower scores were given to the actual performance of equipment and tools which were not known in the farms (score 1, low level). Farmers did not check actual storage capacity in cooperatives warehouse (score 2, basic level).

Assurance activities

Assurance activities scored mostly 1 (basic level), which means that it was not done by own farmers and needed cooperative as the third part. Similarly, the validating and verifying their activities by a technical staff (score 2 , average level). An exception was proactively translating stakeholder requirements (score 2, average level) and using feedback information to update their activities (score 2, average level). All farmers had documentation and record keeping at an average level (score 2), structured, up to date and computerize while cooperative staff also has the same activity to make sure that nothing left behind.

Monitoring system design

Most activities were designed according to guidelines and standards (e.g., JGAP) and by using best available equipment but the methods its need to improve (score 2, average level). Several activities were the hygienic design of equipment, premises, and tools, which was mostly not considered (score 1, basic level); sanitation program, incoming materials control and corrective actions, which were based on own knowledge and experience (score 1, basic level). Cooperatives still not taking microbiological samples (score 1, basic level). However, farmers were using organic fertilizers, applied according to cooperative suggestion (score 3 , advance level).

Output

Table 1 reveals the results for the indicators of the system output. All farmers were audited by cooperative staff and buyers (consumers) representatives (score 2 or 3), did not have major recalls (score 3 ) or complaints about pesticide residues (score 3). Showed better results for few visual complaints (score 3), the cooperative still not established a microbiological sampling plan (score 1) with no idea of criteria (score 1), but was recording the non-conformities of received products (score 3). All were sampling for pesticide residues on a cooperative level (score 2).

\section{Food safety activity assessing}

In order to ensure quality and safety of mandarin orange farmers, cooperatives not only supporting and monitoring cultivation period. Also, invest and construct their warehouse near the production area. The characters of the warehouse are that: (1) the cooperatives construct the warehouse directly and make investments in constructions and facilities; (2) all the input products are monitoring by technical staff and accomplished with cooperatives criteria;(3) most mandarin orange from farms are selling in fresh. 
Table 1. Result of FSMS-DI analysis

\begin{tabular}{|c|c|c|c|}
\hline \multirow{2}{*}{ Indicators } & \multicolumn{3}{|c|}{ Score } \\
\hline & Basic (1) & Average (2) & Advance (3) \\
\hline Actual operation of control activities & & & \\
\hline Availability of procedures & & & $\mathbf{0}$ \\
\hline Compliance to procedures & & & $\mathbf{0}$ \\
\hline Actual hygienic performance of equipment \& facilities & o & & \\
\hline Actual cooling and storage capacity & o & & \\
\hline Assurance activities & & & \\
\hline Sophistication translating external requirements & o & & \\
\hline Extent of systematic use of feedback information & & o & \\
\hline Extent verifying people related performance & o & & \\
\hline Extent verifying equipment \& methods performance & o & & \\
\hline Appropriateness documentation & & $\mathbf{0}$ & \\
\hline Appropriateness record-keeping system & & o & \\
\hline Monitoring system design & & & \\
\hline Appropriateness of risk analysis & & o & \\
\hline Adequacy of analytical methods for microbiological hazards & o & & \\
\hline Adequacy of analytical methods for pesticide residues & & $\mathbf{0}$ & \\
\hline Specificity of microbiological sampling plan & o & & \\
\hline Specificity of pesticides' sampling plan & & & $\mathbf{0}$ \\
\hline System output & & & \\
\hline Type of microbiological complaints & $\mathbf{o}$ & & \\
\hline Type of chemical food safety complaints & & & $\mathbf{0}$ \\
\hline Type of visual quality complaints & & & $\mathbf{0}$ \\
\hline Advancedness of microbiological sampling & $\mathbf{0}$ & & \\
\hline Comprehensiveness of judgment criteria for microbial FS & & & \\
\hline Advancedness of pesticides sampling & & $\mathbf{0}$ & \\
\hline Comprehensiveness of judgment criteria for chemical FS & & & $\mathbf{0}$ \\
\hline Type of non-conformities & & & $\mathbf{0}$ \\
\hline
\end{tabular}

Therefore, cooperative under the food safety management activity has managerial activity and technological aspect integrated into their business activity (Table 2).

Specificity, 8 indicators from managerial aspects and 15 indicators from technological aspects were performed in food safety activities. The 23 indicators were all scored from assigned score 1 to 2 (53\%) to assigned score 2 $3(32 \%)$ and assigned score $3(15 \%)$. This result can be summarized that 68 percent of assessed QA activities from the questionnaires were performed in "lower than moderate" and the other 32 percent of assessed QA activities were performed in "moderate" level. An overall food safety activities by agriculture cooperatives represent a lower level of validation of food quality and safety activities. These indicators could be considered as challenges to the upgrade of food safety activities. 
Proceedings of the $4^{\text {th }}$ International Conference on Agriculture and Forestry, Vol. 3, 2017, pp. 10-15

Table 2. Assigned scores for food safety and quality activities

\begin{tabular}{|c|c|c|c|c|}
\hline \multicolumn{5}{|l|}{ Managerial } \\
\hline Aspects & Indicators & $\begin{array}{l}\text { Overall } \\
\text { score }\end{array}$ & $\begin{array}{l}\text { Mean } \\
\text { score }\end{array}$ & $\begin{array}{l}\text { Assigned } \\
\text { score }\end{array}$ \\
\hline \multirow{3}{*}{ Decision-making } & Identify critical control points & 63 & 1.7 & 1 \\
\hline & Validation & 73 & 2.5 & 1 \\
\hline & Traceability & 86 & 3 & 3 \\
\hline \multirow{2}{*}{ Quality behavior } & Training & 85 & 2.4 & $2-3$ \\
\hline & advice and support farming activity & 85 & 2.7 & $2-3$ \\
\hline \multirow{3}{*}{ Certification (Brand) } & Sampling \& laboratory analysis & 75 & 2.0 & 2 \\
\hline & Cross-check farming activity & 78 & 2.5 & 2 \\
\hline & Documentation \& record & 83 & 3 & 3 \\
\hline \multicolumn{5}{|l|}{ Technological } \\
\hline \multirow{6}{*}{ Cultivation period } & Identification input & 71 & 3 & 3 \\
\hline & Pest identification & 68 & 1.5 & 1 \\
\hline & Chemical compound control & 72 & 2.0 & 2 \\
\hline & Waste system & 69 & 2.0 & 2 \\
\hline & Worker hygiene & 65 & 1.5 & 1 \\
\hline & Equipment hygiene & 65 & 2.5 & 2 \\
\hline \multirow{5}{*}{ Warehouse } & Chemicals & 69 & 2.0 & 2 \\
\hline & Cooling storage & 75 & 2.0 & 2 \\
\hline & Wash equipment hygiene & 72 & 2.0 & 2 \\
\hline & Packaging material & 74 & 2.8 & $2-3$ \\
\hline & Quality control & 73 & 2.8 & $2-3$ \\
\hline \multirow[t]{2}{*}{ Distribution } & Cleaning procedure & 74 & 2.3 & 2 \\
\hline & Cooling transport hygiene & 69 & 1.5 & 1 \\
\hline Retail practices & Traceability & 82 & 3 & 3 \\
\hline Final food preparation & Shelf life & 84 & 2.9 & $2-3$ \\
\hline
\end{tabular}

Note : 0 - 1 Basic, 2 moderate, 2 - 3 Higher than moderate, 3 Advanced

\section{Discussion}

Contract sale between customers with cooperatives demonstrated adjusting levels of food safety activities and less risky organization and chain, associated with the presence of a technical person with expertise in food safety, higher competences of workers and more sophisticated logistic facilities. Moreover, commonly include specifications on quality and safety parameters, which require further coordination between members and the cooperative, and between the cooperative and the customers. These differences can be partially attributed to differences in countries food control agreement.

Furthermore, additional training and advice by the cooperative correlated to farming activities, especially regarding the knowledge-intensive assurance activities. These efforts were triggered by market demands from retailers and other buyers as the cooperative was selling a large percentage of the mandarin oranges via contracts. 


\section{Conclusions}

This study expands the topic by defining the activities through which cooperatives play a role in food quality and safety management in the fresh produce chain. This study identified a two-step role of cooperatives in the supply chain. The first step, they are responsible for supply chain management, including tactical decisions about coordination of quality and safety between farmers and customers. The second step, cooperatives sell the products of their members and make strategic decisions about the governance of food safety requirements in the supply chain, which ultimately may have an outcome single market channel. This condition was linked to cooperatives effort put in a supply chain management and farming activities support during the cultivation period. Such as control activities and assurance activities, training, and advice to the members to implement quality and safety demanded cooperatives, providing logistics, sorting, packaging and traceability of the products.

\section{References}

Altmann, M., M. Wadl, D. Altmann, J. Benzler, T. Eckmanns, G. Krause, and M. Heidein, an der. 2011.Timeliness of surveillance during outbreak of Shiga toxin-producing Escherichia coliinfection, Germany, 2011. Emerging Infectious Diseases. 17.

Barton Behravesh, C., R. K. Mody, J. Jungk, L. Gaul, J. T. Redd, S. Chen, S. Cosgrove, E. Hedican, D.Sweat, L. Chávez- Hauser, S. L. Snow, H. Hanson, T.-A. Nguyen, S. V. Sodha, A. L. Boore,E. Russo, M. Mikoleit, L. Theobald, P. Gerner-Smidt, R. M. Hoekstra, F. J. Angulo, D. L.Swerdlow, R. V. Tauxe, P. M. Griffin, and I. T. Williams. 2011. 2008 Outbreak of SalmonellaSaintpaul Infections Associated with Raw Produce. New England Journal of Medicine.364:918-927.

Cruz, A. G., S. A. Cenci, and M. C. A. Maia. 2006. Quality assurance requirements in produceprocessing. Trends in Food Science \& Technology. 17:406-411.

Godo, Y. (2014). The Japanese Agricultural Cooperative System: An Outline. http://ap.fftc.agnet.org/ap_db.php?id=248\&print=1. (accessed 15 Nov 2016).

Imran, Z., Yamao, M., Hosono, K., and Hiratani, K. (2014). Transformation of Japanese agriculturecooperative toward trans pacific partnerships. Agricultural and Fisheries Economics ofHiroshima University. (14) 16 - 21.

Kupper, G and Batt, P.J, 2009. Barriers to the adoption of quality assurance systems in the food and beverage sector. Online ISSN: 1945-9656.

Laksanalamai, P., L. A. Joseph, B. J. Silk, L. S. Burall, C. L. Tarr, P. Gerner-Smidt, and A. R. Datta. 2012. Genomic Characterization of Listeria monocytogenes Strains Involved in a Multistate Listeriosis Outbreak Associated with Cantaloupe in US. PLoS ONE. 7:e42448.

Luning, P. A., and W. J. Marcelis. 2006. A techno-managerial approach in food quality managementresearch. Trends in Food Science \& Technology. 17:378-385.

Noordhuizen, J.P.T.M and Metz, J.H.M., 2005. Quality control on dairy farms with emphasis on publichealth, food safety, animal health and welfare. Livestock Production Science. 94, 51-59.

Pongvinyoo, P. 2015. Development of Good Agricultural Practices (GAP) in Thailand: A case study of Thai National GAP selected products. Hiroshima University. Doctoral Thesis.

Van Boxstael, S., I. Habib, L. Jacxsens, M. De Vocht, L. Baert, E. Van De Perre, A. Rajkovic, F. Lopez-Galvez, I. Sampers, P. Spanoghe, B. De Meulenaer, and M. Uyttendaele. 2013. Food safetyissues in fresh produce: Bacterial pathogens, viruses and pesticide residues indicated as majorconcerns by stakeholders in the fresh produce chain. Food Control. 32:190-197.

Van de Perre, E., N. Deschuyffeleer, L. Jacxsens, F. Vekeman, W. Van Der Hauwaert, S. Asam, M.Rychlik, F. Devlieghere, and B. De Meulenaer. 2013. Screening of moulds and mycotoxinsintomatoes, bell peppers, onions, soft red fruits and derived tomato products. Food Control.37:167-170.

Verbeke, W., Scholdere, J., and Frewer, L. 2007. Consumer perception of safety in agri-food chain. Safety in the agri-food chain. Wageningen Academic Publishers. pp 619-646.

Waiyeelin. 2016. Integrated Food Control Systems Toward Food-Safety and Trade-Promotion in Myanmar. Hiroshima University. Doctoral Thesis. 